İş ve İnsan Dergisi I The Journal of Human and Work

Y1l | Year: Nisan | April 2018

Cilt-Sayı | Volume-Issue: 5 (1)

ss I pp: $61-73$

doi: 10.18394/iid.325885

e-ISSN 2148-967X

http://dergipark.gov.tr/iid/

Araştırma Makalesi

\title{
Insan Kaynakları Yönetimi Alanındaki Bildirilerin Seyri: Ulusal Yönetim Ve Organizasyon Kongreleri Üzerine Bir Araştırma ${ }^{\text {a }}$
}

\section{Progress of Proceedings in The Field of Human Resources Management: A Research on National Management and Organization Congresses}

\section{Duygu Kızıldă̆a $\breve{a}^{\mathrm{a}}$ Handan Deniz Böyükaslan *,b}

\section{MAKALE BİLGİSI}

Anahtar Kelimeler:

Insan Kaynakları Yönetimi.

Ulusal Yönetim ve

Organizasyon Kongresi,

Insan Kaynaklarl Yönetim

Literatürü, İçerik Analizi,

Türkiye.

Tarihler :

Gelis 04 Temmuz 2017

Düzeltme geliş 12 Eylül

2017

Kabul 16 Ekim 2017

\section{ARTICLE INFO}

\section{Keywords:}

Human Resources

Management, National

Management and

Organization Congress,

Human Resource

Management Literature,

Content Analysis, Turkey.

Article history:

Received 04 July 2017

Received in revised form 12

September 2017

Accepted 16 October 2017

\section{ÖZ}

Bu çalıșmanın amacl, Türkive'de insan kaynakları yönetimi alanında yapılan çalıșmalardaki değişimi Ulusal Yönetim ve Organizasyon Kongreleri kapsaminda incelemektir. Bu bağlamda, düzenlenmeye başladığı ilk yll olan 1993'den 2016 yllına kadar Ulusal Yönetim ve Organizasyon Kongrelerinde yayımlanan bildiri kitaplarındaki insan kaynakları alanindaki bildiriler, bildiri bașlığı, yazar(lar)ın çalıștıkları kurum, yazar sayısı, kullanılan araștırma yöntemi ve örneklem açısından içerik analizine tabi tutulmuştur. Araştırma sonucunda alandaki bildiri sayılarının 2004 yılından itibaren arttı̆̆l, en çok çalışılan konuların kariyer yönetimi, stratejik insan kaynakları yönetimi, performans yönetimi olduğu ve nicel yöntemlerin daha fazla tercih edildiği görülmüsstür.

\footnotetext{
a Bu çalışma 25-27 Mayıs 2017 tarihlerinde düzenlenen 25.Ÿ̈netim ve Organizasyon Kongresi’nde sunulan bildiri çalışmasından türetilmiştir.

a İletişim kurulacak yazar, İzmir Demokrasi Üniversitesi, İktisadi ve İdari Bilimler Fakültesi, İşletme Bölümü, İzmir, Türkiye. E-posta: duygu_kizildag@hotmail.com ORCID:0000-0001-5354-7729

${ }^{*}$, Afyon Kocatepe Üniversitesi, İktisadi ve İdari Bilimler Fakültesi, Işsletme Bölümü, Afyon, Türkiye. E-posta: yumusakipek@aku.edu.tr. ORCID: 0000-0003-0697-9398
} 


\section{GíRiş}

İnsan kaynakları yönetimi, 19. yüzyıl sonunda şekillenmeye başlayan ancak ülkemizde 1980'li yıllar ile birlikte personel yönetiminin yerini alarak önem kazanan bir kavramdır. Amerika Birleşik Devletlerinden yayılan bu kavram, uluslararası ilgi görmüş ve günümüze kadar dinamik bir gelişim süreci izlemiştir. $\mathrm{Bu}$ süreçte yaşanan değişim ve dönüşümler örgütlerdeki insan kaynağının yönetimine de bakışı farklılaştırmıştır. Dolayısıyla insan kaynakları yönetimi sadece akademisyenlerin değil, uygulamacıların da önem verdiği, değişim ve dönüşümleri takip ettiği bir alan haline gelmiştir. İnsan kaynakları yönetimi alanı başlangıçtan günümüze insanı işletmenin hedefleri doğrultusunda etkin şekilde kullanmayı, eşsiz bir kaynak olarak insanın ihtiyaç ve beklentilerini karşılamayı ve gelişimine katkıda bulunmayı amaçlamıştır. Karmaşık bir yapıya sahip olan insan kaynağının özellikleri hem uygulamayı hem de literatürü etkilemiş aynı zamanda bunlardan etkilenmiştir.

Sanayi devrimi ile birlikte ilk personel yönetimi olarak adlandirılan insan kaynakları uygulamalarının daha çok kayıt tutma, dosyalama, bordro hazırlama gibi operasyonel faaliyetler şeklinde ortaya çıktığı bilinmektedir (Van Buren, Greenwood \& Sheehan, 2011; Vani, 2011). 1920'li yıllarda personel yönetiminin sorumluluk alanına sendikal ilişkiler ve çalışan ilişkileri de dahil olmaya başlamış, Hawthorne araştırmaları ile örgütteki insan ilişkilerinin öneminin ortaya konulmasıyla, ücret, motivasyon ve çalışma koşullarına ilişkin düzenlemeler yapılmıştır (Rotich, 2015). 1930'larda ekonomik buhranın etkileri ve İkinci Dünya Savaşı için emek seferberliği personel yönetimi için zorluklar yaratsa da savaşa katılmayan işgücünün verimli kullanılmasına ve performansın artırılmasına yönelik bilimsel yöntemlerin gelişmesine katkı sağlamıştır. Öte yandan İkinci Dünya Savaşı ile birlikte orduda psikolojik testlerin uygulanması personel seçme tekniklerinde önemli gelişmelere neden olmuş; ilgi, yetenek ve beceri testleri seçim sürecinde kullanılmaya başlamıştır. 1940'lı yılların sonlarında ise personel yönetimi mesleki bir çalışma alanı olarak, endüstriyel ilişkiler kapsamında birlikte anıldığı işgücü piyasası analizleri, toplu pazarlık gibi konulardan ayrılmaya başlamıştır (Mahoney \& Deckop, 1986). Personel yönetimini şekillendiren verimlilik odaklı çalışmalar iş tasarımı, seçme ve yerleştirme, çalışmanın fiziki ve psikolojik zorluklarını azaltmaya ilişkin teknikler üzerine yoğunlaşmıştır (Üsdiken \& Wasti, 2002). Yine bu dönemde personel yönetiminin personel seçme, iş değerleme, eğitim, performans gibi alt fonksiyonların kendi alanlarındaki teknik gelişimine odaklanan mikro düzeyde analizler ön planda olmuştur (Sayılar, 2005).

1960'lı yıllarda ise insan davranışlarını inceleyen örgütsel davranış teorisinin personel yönetimi alanını etkilemeye başladığı görülmektedir. $\mathrm{Bu}$ dönemde çalışanların davranışlarını anlama ve yönetmeye odaklanılmış, iş performansı değil örgütsel etkinlik ön plana çıkmıştır (Mahoney \& Deckop, 1986). 1960'lı ve 1970'li yıllarda çalışana sadece iş, çalışma psikolojisi, eğitim ve endüstriyel ilişkiler açısından bakışın yeterli olmadığı anlaşılmış, ayrıca gelişen teknoloji, artan rekabet ve diğer çevresel faktörler, insan kaynağının niteliğini işletmelerin başarılarını belirleyen temel bir unsur haline getirmiştir (Tunçer, 2012). 1980'li y1llardan itibaren çalışanlar masraf unsuru yerine bir yatırım ve rekabet avantajı kaynağı olarak görülerek personel yönetimi kavramı yerine, insan kaynakları yönetimi kavramı kullanılmaya başlanmıştır (Üsdiken \& Wasti, 2002). Ancak çalışanların bir kaynak olarak görülmesiyle birlikte bir üst kavram olarak şekillenen ve yeni işlevleri kurgulayarak kuramsal temellere oturtulmaya çalışılan insan kaynakları yönetimi araştırmalarında mantık temelde yine rasyonel seçim ve kontrol kavramları üzerine olmuştur (Sayılar, 2005). Bu nedenle personel yönetiminden insan kaynakları yönetimine geçiş kimilerine göre özde, kimilerine göre de sadece makyajda ortaya çıkan bir dönüşüm olarak nitelendirilmiştir (Erçek, 2004).

1980'li y1llardan sonra örgütteki insan unsuru; küreselleşme, uluslararası alanda yaşanan rekabet, gelişen teknolojiler, değişen üretim ve yönetim modelleri ile birlikte stratejik bir önem kazanmıştır (Bayat, 2008). Zaman içinde çalışanların eğitim, nitelik ve beklentilerinin artması, işletme boyutları ve faaliyet alanlarının genişlemesi sonucu insan diğer işletme kaynaklarının aksine, bir maliyet unsuru olmaktan çok bir yatırım unsuru olarak ele alınmıştır. Önceleri tepe yönetim tarafından belirlenen plan ve politikaları uygulamakla yetinirken, işletmenin ana stratejilerinin belirlenmesi ve uygulanması sürecine destek olmaya başlayan insan kaynakları yönetimi, dar bir alanda uzmanlaşmış operasyonel birim olmaktan çıkarak stratejik bir birim haline gelmiştir. İnsan kaynağının stratejik olarak tanımlanması ile insan kaynakları yönetimi işlevsellik odaklı çalışmalardan daha makro perspektife kaymış olsa da, stratejik hedeflerle ilişkilendiren, seçme ve yerleştirme, eğitim ve geliştirme, motivasyon ve çalışan bağlılığını sağlama gibi kavramlar yine ön planda tutulmuştur (Bayat, 2008). Bu nedenle insan kaynakları fonksiyonları ve strateji arasındaki ilişkilere dikkat çeken çalışmalarda ilişkiselliğin gözden uzak tutulması eleştirilmiş, insan kaynakları 
uygulamalarının bütüncül bir örüntü içinde düşünülmesi gerektiği vurgulanmıştır (Sayılar, 2005). Dolayısıyla insan kaynakları yönetimine ilişkin araştırmalar, sınırlı bir alana sıkışmış, daha çok insan kaynakları fonksiyonları üzerine çeşitlenmiş, uygulama ve teori arasında uyumsuzluğa sahip, hatta teorik altyapısı yetersiz olarak nitelendirilmiştir (Wright \& McMahan, 1992).

İlgili literatür incelendiğinde, tarihsel süreç içinde insan kaynakları yönetimi alanındaki değişimlerin farklı açılardan değerlendirildiği görülmektedir. Hem yabancı literatürde hem de bu literatürün etkisiyle şekillenen Türk literatüründe alandaki değişimleri, hem akademik hem de uygulama açısından değerlendiren farklı çalışmalar bulunmaktadır. Benzer motivasyondan hareketle bu çalışmada, düzenlenmeye başladığı ilk yıl olan 1993'den 2016 y1lına kadar Ulusal Yönetim ve Organizasyon Kongrelerinde yayımlanan bildiri kitaplarında yer alan insan kaynakları yönetimi bildirileri inceleme konusudur. Alanda bütüncül ve farklı çalışma yapmanın güçlüğü, çalışmaların tekrara dayanması gibi literatürde belirtilen görüşler doğrultusunda, Türkiye'deki insan kaynakları literatüründeki değişimler, benzerlikler ve farklılıklar bildiriler incelenerek ortaya konulmaya çalışılmaktadır. Personel yönetiminden stratejik insan kaynakları yönetimine geçiște yabancı literatürde çalışılan kavramların, alandaki çeşitlenmenin ve eğilimlerin Türkiye'deki insan kaynakları yönetimi alanına yansımaları bildiriler açısından değerlendirilmektedir.

\section{KAVRAMSAL ÇERÇEVE}

Türkiye'de personel/insan kaynakları yönetimi, kamu ve işletme yönetimi alanlarında olduğu gibi gecikerek ve dışarıdan ithal edilen bir alan olarak değerlendirilmekte ve alandaki bilgi birikiminin referans kaynağı büyük ölçüde Amerika Birleşik Devletleri olarak görülmektedir (Aycan, 2001; Üsdiken, 1996; Üsdiken \& Wasti 2002; Sayılar, 2004; Sayılar, 2005, Wasti, 1998). Türkiye'de 1930'lu yıllardan itibaren seçme ve yerleştirme, ücret ve terfi gibi konularda yapılmış çalışmalar olsa da personel yönetiminin ayrı bir disiplin olarak şekillenmesi 1970'li yılların başında gerçekleşmiştir (Üsdiken \& Wasti, 2002). İlk yıllarda insan ilişkileri yaklaşımına yönelim, özellikle işletme alanı açısından bu yaklaşımın sistemleştirici ve yapısalcı yönüne doğru olmuştur (Üsdiken \& Çetin, 1999). 1960'l1 yillarla birlikte ise personel konusu kamu yönetimi ve işçi-işveren ilişkilerinden bağımsız bir kimlik kazanmış ve ilgi personel yönetiminin fonksiyonlarını yerine getirmekte kullanılan tekniklere kaymıştır (Üsdiken \& Wasti, 2002). 1980'li y1llarda insan kaynakları yönetimi söylemi üzerinde durulmaya başlanmış (Akar, 2013), kendini gösteren esnekleştirici anlayış ise 1990’lı yıllarda yazına etki etmiştir. 1990'lı yıllarda insan kaynakları yönetiminde önemli değişiklikler gözlenmiş, stratejik bakış açışı önem kazanmış çalışanlar masraf değil, kaynak olarak görülmeye başlanmıștır. 2000'lerden sonra ise insan kaynakları yönetimi işletmelerin önemli bir alanı haline gelmiştir (Eroğlu, 2016).

Türkiye'de 1950'lerden sonra personel/insan kaynakları yönetimi alanının gelişmesini destekleyen kurumların da kurulduğu görülmektedir. Türkiye ve Orta Doğu Kamu İdaresi Enstitüsü (TODAİE) 1952 y1lında faaliyete başlamış ve 1954 yılında, "İnsan İlişkileri" konulu bir seminer gerçekleştirilmiştir. 1965 yılında ise kamu ve özel sektör şirketlerinin verimliliğini artırmak amaciyla Milli Prodüktivite Merkezi (MPM) kurulmuştur (Tüzüner, 2014). 1971 yılında personel yönetimi konusunda dünyada üretilen fikir, yöntem ve tekniklerin Türkiye'ye transferi ve personel yönetimi mesleğinin Türkiye'de geliştirilmesine katkıda bulunmak amacıyla Personel Yöneticileri Derneği (PERYÖN) kurulmuştur. 1990'l1 yıllarda ise insan kaynakları yönetimi konularında uzmanlaşmış Hay Group gibi danışmanlık şirketleri Türkiye'de faaliyet göstermeye başlamıştır (Erçek, 2004).

Türkiye'de insan kaynakları yönetimi alanında bilim üreten ve yayan yeterince kurum ve kuruluş bulunmadığından, alana yönelik bilimsel katkıların daha çok üniversitelerden geldiği görülmektedir (Benligiray, 2009). 1968 y1lında İstanbul Üniversitesinde İşletme Fakültesi kurulmuş ve bünyesinde davranış bilimleri ve personel yönetimi alanları ayrı kürsüler olarak oluşturulmuştur (Üsdiken \& Çetin, 1999). Şubat 1998'de İstanbul Üniversitesi İşletme Fakültesi Personel Yönetimi Bölümünün adı İnsan Kaynakları Yönetimi Bölümü olarak değiştirilmiştir (Tüzüner, 2014). İnsan kaynakları yönetimi alanında ilk lisans programı 2008 y1lında Sakarya Üniversitesinde ve ilk doktora programı 2012 y1lında Ankara Üniversitesinde kurulmuştur (Eroğlu, 2016). Açılan bu bölümler, hem teoride hem de uygulamada alanın şekillenmesine etki etmiştir.

Türkiye'de personel yönetiminden insan kaynakları yönetimine geçişte yaşanan değişimin, yine daha çok Amerika Birleşik Devletleri'nden türetilen bilimsel çalışmalara da yansıdığı görülmektedir. Örneğin, Üsdiken ve Wasti (2002)'nin Amme İdaresi Dergisi, Eskişehir Anadolu Üniversitesi İktisadi ve İdari Bilimler Fakültesi Dergisi, İstanbul Üniversitesi İşletme Fakültesi Dergisi ve Orta Doğu 
Teknik Üniversitesi Gelişme Dergisi'nde 19721999 yılları arasında personel ve insan kaynakları yönetimi alanında yazılan makalelerin seyrini incelediği çalışmalarında, eğitim ve geliştirme, temin ve seçim ile performans değerlendirmenin en çok ilgi çeken konular olduğu ortaya çıkmıştır. 1990'lı y1llarla birlikte performans değerlendirme, eğitim ve geliştirme konularında yapılmış çalışmalarda düşüş, buna karşılık kariyer planlaması konusunda ise artış gözlenmiştir. Başlangıçta sistemleştirme üzerinde duran çalışmaların insancıllaştırmaya doğru kaydığı ve 1990'lı yıllarla beraber geliştirme, rehberlik, öğrenme ve kariyer üzerinde durulduğu görülmüştür. İşletmeler üzerine yapılan araştırmalar da ise kamu sektörününün sayıca fazlalığı dikkat çekmiştir.

Benzer şekilde Sayılar (2005), insan kaynakları yönetimi literatürünün izlediği süreci, Türkiye'de yapılan çalışmaların alanda yaşanan değişimlerle ne derecede ve nasıl ilişkilendiğini 2000-2004 yılları arasındaki Ulusal Yönetim ve Organizasyon Kongrelerinde insan kaynakları yönetimiyle ilgili bildirileri inceleyerek değerlendirmiştir. Araştırmada Üsdiken ve Wasti (2002) tarafindan geliştirilen üç boyut (personel alanına yaklaşım, Türkiye ortamına yaklaşım ve bilgi üretmeye yaklaşım) temel alınmış̧ır. $\mathrm{Bu}$ araştırmanın bulguları, kongrelerde insan kaynakları yönetiminin fonksiyonları ya da tekniklerinin ağırlıklı olarak inceleme konusu yapıldığını, daha üst düzeyli analizlerin ilgi görmeye başlamakla birlikte halen azınlıkta olduğunu, görgül çalışmaların sayıca fazla olduğu, kuramsal alandaki etkileşimlerin ise sınırlı ve yüzeysel biçimde gerçekleştiğini göstermiştir. Ayrıca önceki araştırma bulgularından farklı olarak bilime katkı yapma amacı taşıyan çalışmaların alanda yer bulmaya başladığı vurgulanmıştır.

Tuncay (2015) ise, yüksek lisans tez çalışmasında Türkiye ve Amerika Birleşik Devletleri insan kaynakları yönetimi yazınını 2004-2015 yılları arasında ele alarak kıyaslamış ve Türkiye'deki insan kaynakları yazınının, 2004 - 2015 döneminde de Amerika Birleşik Devletleri yazınını model almaya devam ettiğini ortaya koymuştur. Her iki ülkenin yazınında en çok kullanılmış ilk 100 kelimeden 63 'ünün aynı olduğu görülmüștür. Yine her iki ülke yazınında en sık kullanılan kelimelerin başında performans gelmektedir. Performans konusu, Amerika Birleşik Devletleri yazınında, 2004, 2005 ve 2006 yıllarında üzerinde en çok çalışma yapılan konu iken, Türkiye'de ise konu ile ilgili çalışmalar 2007 yılında yoğunlaşmaya başlamıştır.

Koç, Türker ve Özcan (2013) de, insan kaynakları yönetiminin akademik konumunu incelemek üzere 2005-2012 yılları arasında gerçekleşen Ulusal
Yönetim ve Organizasyon Kongrelerinde insan kaynakları yönetimi alanında sunulan bildirileri incelemiştir. Araştırmada alanda yapılan çalışmalarda mikro analiz düzeyinin benimsendiği, nicel, kesitsel ve birincil kaynaklara dayalı görgül çalışmaların ön plana çıktığı görülmüştür. Konular açısından ise insan kaynakları uygulamalarının çalışan ve işletme performansı ile ilişkilerinin üzerinde durulduğu belirlenmiştir.

Üniversitelerin alana katkısı Benligiray (2009) tarafindan, 1983-2008 yılları arasinda insan kaynakları yönetimi alanında yapılmış tez çalışmaları doğrultusunda incelemiştir. Araştırmada son 6 yılda yapılan tezlerin, 25 yıllık dönemde yapılan tüm tezlerin yarısını oluşturduğu görülmüştür. İncelenen 1123 tezin yüzde 44'ü Marmara Üniversitesi, İstanbul Üniversitesi ve Gazi Üniversitesi'nde yapılmış, bu alanda tezlerin yapıldığı ilk on üniversite ise; Marmara Üniversitesi, İstanbul Üniversitesi, Gazi Üniversitesi, Dokuz Eylül Üniversitesi, Ankara Üniversitesi, Sakarya Üniversitesi, Anadolu Üniversitesi, Uludağ Üniversitesi, Hacettepe Üniversitesi ve Yıldız Teknik Üniversitesi şeklinde sıralanmıştır. İstanbul Üniversitesi insan kaynakları yönetimi alanında en çok doktora tezinin, Marmara Üniversitesi ise insan kaynakları yönetimi alanında en çok yüksek lisans tezinin yapıldığı üniversitedir. 25 yıllık periyodun her döneminde en çok tez yapılan temalardan biri "performans yönetimi"dir. Sıkça çalışılan diğer konular arasında ödül ve teşvik yönetimi, iş doyumu, örgütsel bağll1ık ve motivasyon, eğitim ve geliştirme gelmektedir. Tezlerin uygulama alanları incelendiğinde en fazla tezin kamu kurum ve kuruluşlarında yapıldığ 1 görülmüştür. Diğer uygulama alanları ise bankalar ve turizm işletmeleri, sağlık kurum ve kuruluşları ile imalat işletmeleridir.

İnsan kaynakları yönetiminin kurumlaşması ile ilgili çalışmaların ve güncel eğilimlerin literatüre yansımasını Yapıcı-Akar, Dirlik, Kıymalığlu, Yurtseven ve Boz (2011), 1998-2008 yillar1 arasında Sosyal Bilimler Atıf İndeksi'nde (SSCI) taranan ve isminde insan, personel ya da işgücü kelimeleri geçen dergiler üzerinden incelemiştir. Araştırmada güncel eğilimlerin "insan kaynakları yönetimi uygulama ve fonksiyonları" ile "yeni istihdam biçimleri” üzerinde yoğunlaştığ saptanmıştır. Ayrıca küresel koşulların, bölgesel işletme uygulamaları üzerinde eş biçimlilik yarattığ 1 tespit edilmiştir. Bu noktada, Amerikan modelinin Avrupa'da da etkili olduğu ve bu nedenle insan kaynakları yönetimi açısından Avrupa'ya özgü tek bir modelin olmadığı görülmüştür.

Benzer olarak Akar (2013) insan kaynakları yönetimi alanında egemen olan bakış açısını 
belirlemek üzere, 2000-2009 yılları arasındaki Yönetim Araştırmaları Dergisi, İş-Güç, Endüstri İlişkileri ve İnsan Kaynakları Dergisi ile bu yıllar arasındaki Ulusal Yönetim ve Organizasyon Kongreleri Bildiri Kitaplarını analiz etmiştir. Araştırmada incelenen çalışmaların; insan kaynakları yönetimi fonksiyonları ve uygulamaları, insan kaynakları yönetimi söyleminin temelleri ve gelişimi ile çalışma hayatındaki olumsuz davranışlar temalarında olduğu görülmüştür. İncelenen çalışmaların yarısı insan kaynakları yönetimi fonksiyonları ve uygulamaları ile ilgilidir. İncelenen bu çalışmalarda 1lımlı bir bakış açısı olduğu; yetiştirme, geliştirme ve motivasyon süreçlerine dikkat çekildiği görülmüştür. Bunun yanında çalışmalarda eleştirel yaklaşımın etkisinin göreceli olarak daha sınırlı kaldığı tespit edilmiştir. Alanın şekillenmesine katkı sağladığı düşünülen HRdergi ve Capital dergilerinin etkisi Sağlam Arı ve Boylu (2015) tarafindan, 2003-2012 y1lları arasında bu dergilerdeki, başlık ve içeriklerinde insan kaynakları yönetimi alanına ilişkin konuların yer aldığ 1 yazıların incelenmesiyle belirlenmeye çalışılmıştır. Araştırma sonucunda HRdergi'de davranışsal süreçler, kadrolama ve insan kaynakları geliştirme konularında; Capital dergisinde ise davranışsal süreçlere artan bir biçimde yer verildiği gözlenmiştir. İnsan kaynaklarının işletmelerdeki yeri, rolü ve önemi açısından ise, insan kaynaklarının stratejik ortaklığının üst yönetime ve diğer bölümlere ispatlanması, insan kaynaklarının pazarlanması gibi ifadelerle insan kaynakları yöneticilerinin yapması gerekenleri vurgulayan yazıların yer aldığg görülmüştür.

\section{ARASTIRMANIN YÖNTEMI}

$\mathrm{Bu}$ araștırmada temel soru Türkiye'de insan kaynakları yönetimi literatüründe yapılan bildiri çalışmalarında yaşanan değişimlerin neler olduğudur. $\mathrm{Bu}$ soru doğrultusunda araştırmanın kapsamını, düzenlenmeye başladığı ilk yıl olan 1993'den 2016 yılına kadar Ulusal Yönetim ve Organizasyon Kongrelerinde yayımlanan bildiri kitaplarındaki insan kaynakları alanındaki bildiri çalışmaları oluşturmaktadır. Araştırmada içerik analizi yönteminden yararlanılmıştır. Bildiriler; bildiri başlığı, yazar(lar)ın çalıştıkları kurum, yazar sayısı, kullanılan araştırma yöntemi ve örneklem açısından incelenmiştir.

Bildiri başlıklarının içerik analizi ile incelenmesinde kullanılacak boyutların belirlenmesinde alanda yapılmış benzer çalışmalardaki (Akar, 2013; Benligiray, 2009; Sayılar, 2005; Üsdiken \& Wasti, 2002; Yapıcı-Akar vd., 2011) boyutlar incelenmiş ve Benligiray (2009)'ın çalışmasında kullandığı tema ayrımından ve alandaki uzman araştırmacıların görüşlerinden yararlanılmıştır. Alt tema başlıkları ise ana tema ayrımının alındığı çalışmadan esinlenilerek araștırmacılar tarafindan belirlenmiștir. Benligiray (2009) çalışmasında temaları genel insan kaynakları ve yönetimi ile insan kaynakları işlevleri olarak ikiye ayırmıştır. Çalışmada bu iki ana temaya benzer şekilde bir ayrım kullanılarak yapılan içerik analizi şöyle gerçekleşmiştir:

1993'den 2016 yılına kadar Ulusal Yönetim ve Organizasyon Kongrelerinde yayımlanan bildiri kitaplarındaki insan kaynakları yönetimi alanında yapılan bildiriler belirlenmiştir. 1993 yılında yapılan birinci, 1995 yılında yapılan üçüncü ve 1997 yılında yapılan beşinci kongrenin bildiri kitapları yayınlamadığı için bu kongrelerde yer alan bildiriler araştırmaya dahil edilmemiştir. Kongre bildiri kitaplarının bir kısmında "İnsan Kaynakları Yönetimi” alanı başlık olarak ayrılmış ve ilgili bildiriler bu başlık altına toplanmışken, bildiri kitaplarının bir kısmında bu ayrım yapılmamıştır. Ayrıca özellikle son beş yıla ait bildirilerde örgütsel davranış alanında da insan kaynakları ile ilişkili bildirilerin yer aldığı görülmüştür. Çalışmada kullanılacak bildirileri belirleyebilmek için araştırmacılar tarafindan birtakım seçim kriterleri belirlenmiştir. "İnsan Kaynakları Yönetimi” alanı ayrılmış olan bildiri kitaplarında bu bildirilerin tamamı ve alan ayrımı yapılmayan bildiri kitaplarında ise başlıklarında "insan kaynakları yönetimi", "çok uluslu insan kaynakları yönetimi”, "stratejik insan kaynakları yönetimi", "yetkinlik bazlı insan kaynakları yönetimi" ile "insan kaynakları planlaması", "ișe alım", “eğitim", "performans yönetimi", “ücret yönetimi” ve "kariyer yönetimi" gibi insan kaynakları fonksiyonları, bu fonksiyonlarla ilişkili kavramlar (iş analizi, mülakat, kişilik testi, işten ayrılma mülakatı vb.) taranmıştır. $\mathrm{Bu}$ kriterlere uygun olarak her bir bildiri kitabı araştırmacılar tarafindan birlikte incelenmiş ve seçilen bildiriler Excel tablosu haline getirilmiştir. Araştırmacılar tablo oluşturma sürecinde alanda çalışmaları olan bir başka araştırmacının da değerlendirmesine başvurmuştur. Bildiriler kongre yılına, bildiri yazar(lar)ının kurumlarına, yazar sayısına, türlerine (teorik, görgül ve ölçek geliştirme), benimsenen yönteme (nicel, nitel, karma) ve kullanılan tekniğe (anket, mülakat, gözlem, karma, diğer) göre sinıflandırılmıştır.

Bildiriler Benligiray (2009)'ın çalışması doğrultusunda insan kaynakları ve yönetimi ile insan kaynakları fonksiyonları olarak iki temaya ayrılmıştır. İnsan kaynakları ve yönetimi temasındaki bildiriler; stratejik insan kaynakları yönetimi, genel insan kaynakları yönetimi, yetkinlik 
bazlı insan kaynakları yönetimi, insan kaynakları yönetimi sorunları - kriz, insan kaynakları yönetimi ve işveren markası, insan kaynakları yönetimi ve kuşaklar, insan kaynakları yöneticileri-çalışanları, çok uluslu insan kaynakları yönetimi, insan kaynakları yönetimi ve kalite sistemleri ve personelden insan kaynakları yönetimine geçiş olmak üzere on alt temaya ayrılmıştır. İnsan kaynakları fonksiyonları temasındaki bildiriler ise; kariyer yönetimi, performans yönetimi, işe alımseçme ve yerleştirme, endüstri ilişkileri, iş hukuku ve düzenlemeler, ücret yönetimi, eğitim ve geliştirme, iş sağlığı ve güvenliği, insan kaynakları yönetim bilgi sistemleri, insan kaynakları planlaması, işten ayrılma, ödül, teşvik ve motivasyon, disiplin uygulamaları ve iş analizi olmak üzere on üç alt temaya ayrılmıştır. Araştırmacılar tarafından birlikte sınıflandırılan bildiriler belirli periyotlarla alanda çalışmaları olan bir başka araştırmacı tarafindan kontrol edilmiştir.

Tema ve alt tema ayrimı sonrasında bildirilerin kongre yılına, bildiri yazar(lar)ının kurumlarına, yazar sayısına, türlerine (teorik, görgül ve ölçek geliştirme), benimsenen yönteme (nicel, nitel, karma) ve kullanılan tekniğe (anket, mülakat, gözlem, karma, diğer) göre sinıflandırılması yeniden kontrol edilmiştir.

\section{BULGULAR}

Araştırma doğrultusunda yapılan içerik analizi sonucunda elde edilen sonuçlar grafik, frekans ve

Tablo 1: Kongrelerde Insan Kaynaklan Yönetimi Alanındaki Bildiriler

\begin{tabular}{|c|c|c|c|c|c|}
\hline Kongre & Yal & Düzenleyen Kurum & $\begin{array}{c}\text { Toplam } \\
\text { Bildiri } \\
\text { Sayısı }\end{array}$ & $\begin{array}{c}\text { IKY } \\
\text { Alanindaki } \\
\text { Bildiri } \\
\text { Sayusı } \\
\end{array}$ & $\begin{array}{c}\text { Oran } \\
(96)\end{array}$ \\
\hline 1. Kongre & 1993 & İstanbul Ûniversitesi-Boğaziçi Ūniversitesi (Yaymlanmadı) & 37 & - & - \\
\hline 2. Kongre & 1994 & Dokuz Eylūl Ûniversitesi İ̧̧letme Fakūltesi & 38 & 4 & 11 \\
\hline 3. Kongre & 1995 & İstanbul Teknik Ûniversitesi İgletme Mühn Böl. (Yaymlanmada) & 84 & - & $\cdot$ \\
\hline 4. Kongre & 1996 & ODTÛ i. B. B. İqletme Bölümũ & 19 & 2 & 11 \\
\hline 5. Kongre & 1997 & Başkent Ûniversitesi I.I.B.F. Į̇letme Bölümủ (Yaymlanmadi) & 41 & - & - \\
\hline 6. Kongre & 1998 & Anadolu Ûniversitesi & 31 & 1 & 3 \\
\hline 7. Kongre & 1999 & İstanbul Bilgi Üniversitesi & 45 & 9 & 20 \\
\hline 8. Kongre & 2000 & Erciyes Üniversitesi I.I.B.F. & 62 & 14 & 23 \\
\hline 9. Kongre & 2001 & İstanbul Üniversitesi İ̧̧letme Fakültesi & 72 & 9 & 13 \\
\hline 10. Kongre & 2002 & Akdeniz Unaiversitesi I.I.B.F. & 79 & 14 & 18 \\
\hline 11. Kongre & 2003 & Afyon Kocatepe Universitesi I.I.B.F. & ss & 7 & 8 \\
\hline 12. Kongre & 2004 & Uludağ Ūniversitesi İI.B.F. Į̇letme Bölümuี & 96 & 11 & 11 \\
\hline 13. Kongre & 2005 & Marmara Ûniversitesi & 85 & 15 & 18 \\
\hline 14. Kongre & 2006 & Atatürk Ûnitersitesi & 103 & 15 & 15 \\
\hline 15. Kongre & 2007 & Sakarya Ûniversitesi & 122 & 16 & 13 \\
\hline 16. Kongre & 2008 & İstanbul Kũltür Û̉niversitesi & 141 & 17 & 12 \\
\hline 17. Kongre & 2009 & Eskişehir Osmangazi Ũniversitesi L. I. B.F. İşletme Bōlūmū & 130 & 21 & 16 \\
\hline 18. Kongre & 2010 & Çukurova Ûniversitesi II I B.F. Ị̇letme Bōlūmũ & 114 & 19 & 17 \\
\hline 19. Kongre & 2011 & Çanakkale 18 Mart Unniversitesi & 135 & 30 & 22 \\
\hline 20. Kongre & 2012 & Dokuz Eylúl Û̉niversitesi İ̧̨letme Fakūltesi & 132 & 26 & 20 \\
\hline 21. Kongre & 2013 & Dumlupmar Ûniversitesi I.I.B.F. İgletme Bōlūmũ & 136 & 24 & 18 \\
\hline 22. Kongre & 2014 & Selçuk Ûniversitesi I.I.B.F. & 141 & 20 & 14 \\
\hline 23. Kongre & 2015 & Muğla Srtika Koçman Üniversitesi İ.̇.B.F. & 155 & 37 & 24 \\
\hline 24. Kongre & 2016 & Sabancı Ûniversitesi Yönetim Bilimleri Fakültesí & 119 & 20 & 17 \\
\hline
\end{tabular}


Tablo 2: Yazar Sayısına Göre Bild iriler

\begin{tabular}{|c|c|c|c|c|c|c|c|c|}
\hline Kongre & Tek Yazar & İki Yazar & $\overline{\mathrm{U}}_{\varphi}$ Yazar & Dört Yazar & Bes Yazar & Aln Yazar & $\begin{array}{l}\text { Toplam } \\
\text { Bild iri } \\
\text { Sayra }\end{array}$ & $\begin{array}{c}\text { Toplam } \\
\text { Yazar } \\
\text { Sayıs }\end{array}$ \\
\hline 2. Kongre & 4 & - & - & - & - & - & 4 & 4 \\
\hline 6. Kongre & 1 & - & - & - & - & - & 1 & 1 \\
\hline 9. Kongre & 4 & 4 & 1 & - & - & - & 9 & 15 \\
\hline 10. Kongre & 6 & 5 & 3 & - & - & - & 14 & 25 \\
\hline 11. Kongre & & 5 & 2 & - & - & - & 7 & 16 \\
\hline 15. Kongre & 4 & 5 & 6 & 1 & - & - & 16 & 36 \\
\hline 16. Kongre & 3 & 10 & 2 & 1 & 1 & - & 17 & 38 \\
\hline 17. Kongre & 9 & 7 & 5 & - & - & - & 21 & 38 \\
\hline 18. Kongre & 3 & 12 & 4 & - & - & - & 19 & 39 \\
\hline 19. Kongre & 5 & 14 & 8 & 2 & 1 & - & 30 & 70 \\
\hline 20. Kongre & 8 & 15 & 1 & 2 & - & - & 26 & 49 \\
\hline 21. Kongre & 7 & 9 & 5 & 2 & 1 & - & 24 & 53 \\
\hline
\end{tabular}

yüzde tablolarına dönüştürülmüştür. Öncelikle insan kaynakları yönetimi alanındaki bildirilerin kongrelerde nasıl bir artış gösterdiği belirlenmeye çalışılmıştır. Bu doğrultuda, Ulusal Yönetim ve Organizasyon Kongrelerinde insan kaynakları yönetimi alanındaki bildiri sayılarının 2004 yılından itibaren artış gösterdiği görülmüştür. 2015 yılındaki kongrede alandaki bildiri sayısı toplam bildirilerin \%24'üne ulaşmıştır. Son on yılda kongrelerdeki insan kaynakları yönetimi alanındaki bildirilerin toplam bildirilere oranına bakıldığında, oranda büyük bir artış ya da azalış olmadığı belirlenmiştir. Toplam bildiri sayısının artışına paralel olarak alandaki bildirilerin de sayısında yıllara göre çok düzenli olmasa da bir artış olduğu görülmektedir. (Bkz. Tablo 1)

Kongrelerde sunulan bildiriler yazar sayıları açısından değerlendirildiğinde iki yazarlı bildiri sayısının daha fazla olduğu görülmektedir. 2000 yılındaki kongrede ilk kez üç yazarlı, 2004 yılındaki kongrede ilk kez dört ve beş yazarlı, 2014 yılındaki kongrede ise ilk kez altı yazarlı bildiriler yer almıştır. (Bkz. Tablo 2)

Çalışmanın amacı doğrultusunda, insan kaynakları yönetimi alanındaki bildirilerin belirlenen ana ve alt temalara göre nasıl bir dağılım sergiledikleri saptanmıştır. Genel olarak kongrelerde sunulan bildirilerin temaları incelendiğinde en sık çalışılan ilk beş alt temanın; kariyer yönetimi, stratejik insan kaynakları yönetimi, performans yönetimi, genel insan kaynakları yönetimi uygulamaları ve işe alım, seçme ve yerleştirme olarak sıralandığ görülmektedir. (Bkz. Tablo 3)

Kongrede düzenlendiği ilk yıllardan itibaren performans yönetimi ve kariyer yönetimi temalarında hazırlanmış bildiriler yer almaktadır. Son dönemlerde bu iki konunun çalış1ldı̆̆ bildirilerin sayısının fazlalaştı̆̆ı görülmektedir. Stratejik insan kaynakları yönetimi ile ilgili ilk bildiri çalışması ise 2000 yılında düzenlenen kongrede yer almıştır. Performans yönetiminin kongrelerde en fazla çalışılan konulardan olması, daha önce yapılan ve yazında en fazla çalışılan konunun performans yönetimi olduğunu belirten çalışmalarla (Benligiray, 2009; Koç vd., 2013; Tuncay, 2015; Üsdiken \& Wasti, 2002) benzerlik göstermektedir.

Bildiriler yöntem açısından incelendiğinde, nicel yöntemlerin tercih edildiği ve anketin en fazla kullanılan veri toplama tekniği olduğu görülmektedir. Düzenlendiği ilk yıllarından itibaren sayıca fazla olmasa da teorik çalışmalar kongrede yer almaktadır. Bildirilerde nicel yöntemlerin 
Tablo 3: Tema ve Alt Temalarına Göre Bildiriler

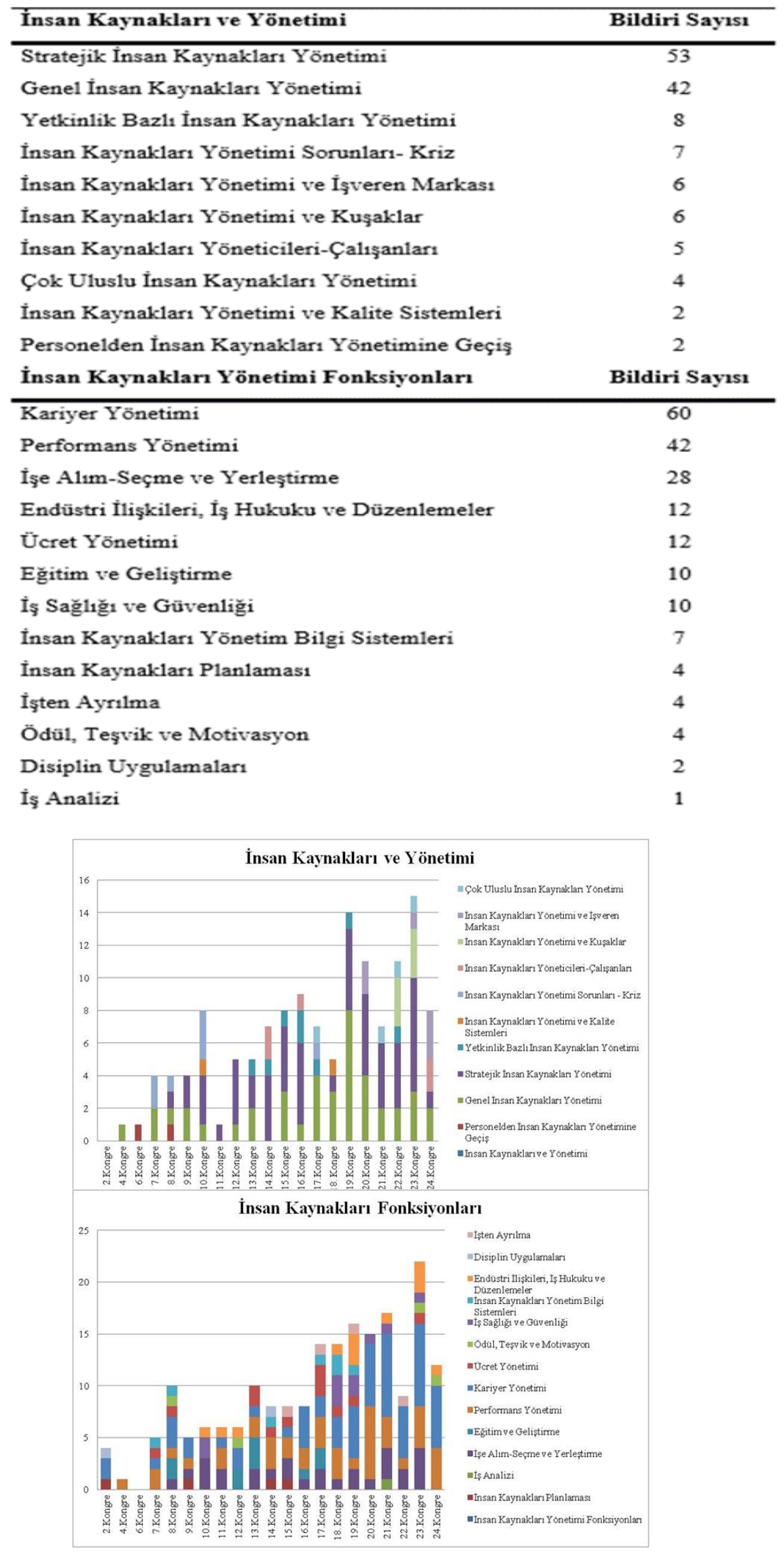

Şekil 1: Kongrelere Göre Bildirilerin Temaları 
Tablo 4: Bildirilerde Kullanılan Yöntemler

\begin{tabular}{|c|c|c|c|c|c|c|c|c|c|c|c|}
\hline \multirow{2}{*}{ Kongre } & \multicolumn{3}{|c|}{ Bildiri Çalıșmasının Tūrü } & \multicolumn{3}{|c|}{$\begin{array}{l}\text { Benimsenen } \\
\text { Yöntem }\end{array}$} & \multicolumn{5}{|c|}{$\begin{array}{l}\text { Veri Toplama } \\
\text { Telniği }\end{array}$} \\
\hline & Teorili & Görgül & Ōlçelz Geliştirme & Nicel & Nitel & Karma & Anket & Mülakizat & Gözlem & Karma & Diğer \\
\hline 2.Kongre & 2 & 2 & - & 2 & - & - & 2 & - & - & - & - \\
\hline 4-Kongre & - & 2 & - & 1 & - & 1 & 1 & - & - & 1 & - \\
\hline 6.Kongre & 1 & - & - & - & - & - & - & - & - & - & - \\
\hline 7.Kongre & 2 & 7 & - & 2 & 3 & 2 & 2 & 2 & 1 & 2 & - \\
\hline S.Kongre & - & 14 & - & 11 & 1 & 2 & 11 & 1 & - & 2 & - \\
\hline 9.Kongre & - & 9 & - & 4 & 2 & 3 & 4 & - & - & 5 & - \\
\hline 10.Kongre & 2 & 12 & - & 6 & 4 & 2 & 6 & 1 & - & 2 & 3 \\
\hline 11.Kongre & - & 6 & 1 & 4 & 1 & 1 & 4 & - & - & 2 & - \\
\hline 12.Kongre & 2 & 9 & - & 6 & 2 & 1 & 6 & 1 & - & 1 & 1 \\
\hline 13.Kongre & - & 15 & - & 10 & 2 & 3 & 9 & 1 & - & 3 & 2 \\
\hline 14Kongre & 1 & 14 & - & 6 & 5 & 3 & 6 & 1 & - & 5 & 2 \\
\hline 15.Kongre & 2 & 14 & - & 8 & 4 & 2 & 6 & - & - & 4 & 4 \\
\hline 16.Kongre & 2 & 15 & - & 8 & 6 & 1 & 8 & 4 & - & 3 & - \\
\hline 17.Kongre & 3 & 18 & - & 9 & 7 & 2 & 9 & 2 & - & 3 & 3 \\
\hline 18.Kongre & - & 19 & - & 14 & 5 & - & 14 & - & - & 2 & 3 \\
\hline 19.Kongre & 1 & 29 & - & 18 & 8 & 3 & 18 & 3 & - & 4 & 4 \\
\hline 20.Kongre & 1 & 25 & - & 19 & 4 & 2 & 18 & - & - & 3 & 4 \\
\hline 21.Kongre & - & 24 & - & 18 & 6 & - & 18 & 2 & - & 1 & 3 \\
\hline 22.Kongre & - & 19 & 1 & 10 & 9 & - & 9 & 1 & - & 4 & 5 \\
\hline 23-Kongre & 1 & 35 & 1 & 22 & 8 & 5 & 21 & 3 & - & 8 & 3 \\
\hline 24.Kongre & 1 & 19 & - & 16 & 2 & 1 & 16 & 1 & - & 2 & - \\
\hline
\end{tabular}

tercihi, yönetim yazının yöntem açısından tercihi ile paralellik göstermektedir (Sayılar, 2005; Üsdiken \& Wasti, 2002). (Bkz. Tablo 4)

Kongrede sunulan bildiriler örneklem açısından incelendiğinde bankacılık ve finans sektörü ile turizm sektörünün en fazla bildiri çalışmasının yapıldığ1 ilk iki sektör olduğu görülmektedir. Yine bildirilerde ISO 100, ISO 500 ve ISO 1000 listelerinde yer alan işletmelerin uygulama alanı olarak tercih edildiği görülmektedir. Benligiray (2009)'ın çalışmasında da benzer şekilde bankalar ve turizm işletmeleri ile sağlık kurum ve kuruluşları tez çalışmalarında en çok uygulamanın yapıldığ örneklemler arasındadır. (Bkz. Tablo 5)

Kongrelere bildiri sunmak üzere katılan araştırmacıların üniversiteleri incelendiğinde, ilk on üniversitenin sirasıly; İstanbul Üniversitesi, Sakarya Üniversitesi, Marmara Üniversitesi, Dokuz Eylül Üniversitesi, Kocaeli Üniversitesi, İstanbul
Teknik Üniversitesi, Yıldız Teknik Üniversitesi, Doğu Akdeniz Üniversitesi, Kara Harp Okulu ve Sütçü İmam Üniversitesi olduğu görülmektedir. İstanbul ve Marmara Üniversitelerinin kongreye en çok katılan üniversiteler olması, tez çalışmaları ile alana katkı üniversitelerin incelendiği çalışma ile paralellik göstermektedir (Benligiray, 2009). Ayrıca ülkemizde ilk insan kaynakları yönetimi kürsünün oluşturulduğu İstanbul Üniversitesi'nin ve alanda ilk lisans programının açıldığı Sakarya Üniversitesi'nin kongreye insan kaynakları alanında katılım sağlayan ilk iki üniversite olduğu görülmektedir. $\mathrm{Bu}$ üniversitelerin kongre katılımında üst sıralarda yer alması, öncü kurumlar olarak alanın şekillenmesine etki ettiklerinin bir göstergesi olarak değerlendirilebilir. (Bkz Tablo 6)

Y1llara göre insan kaynakları yönetimi alanında bildiri çalışmalarını sunmak üzere kongrelere katılan üniversite ve kurum sayısına bakıldığında, özellikle son yıllarda artış olduğu görülmektedir. İlk 
Tablo 5: Bildirilerde Öne Çıkan Örneklem

\begin{tabular}{lclc}
\hline Öne Çıkan Sektörler (İlk 5) & Bildiri Sayısı & Öne Çıkan İșletmeler (İlk 5) & Bildiri Sayısı \\
\hline Bankacılık ve Finans Sektörü & 21 & ISO 500'de Yer Alan işletmeler & 22 \\
Turizm Sektörü & 16 & PERYÖN Üyesi İșletmeler & 7 \\
Sağlık Sektörü & 16 & ISO 1000'de Yer Alan işletmeler & 6 \\
Tekstil Sektörü & 14 & ISO 100'de Yer Alan işletmeler & 5 \\
Savunma Sanayi Sektörü & 6 & Ticaret Odasına Kayıtlı I̦șletmeler & 2 \\
\hline
\end{tabular}

Tablo 6: Kongreye Katılım Sayısına Göre İlk 10 Üniversite

\begin{tabular}{lc}
\hline $\begin{array}{l}\text { Kongreye İnsan Kaynakları Alanında } \\
\text { Katılan Üniversiteler }\end{array}$ & Katılım Sayısı \\
\hline İstanbul Üniversitesi & 18 \\
Sakarya Üniversitesi & 16 \\
Marmara Üniversitesi & 11 \\
Dokuz Eylül Üniversitesi & 9 \\
Kocaeli Üniversitesi & 9 \\
İstanbul Teknik Üniversitesi & 8 \\
Yıldız Teknik Üniversitesi & 8 \\
Doğu Akdeniz Üniversitesi & 7 \\
Kara Harp Okulu & 7 \\
Sütçü İmam Üniversitesi & 7 \\
\hline
\end{tabular}

kongreden günümüze insan kaynakları yönetimi alanının gelişmesini sağlayan MPM gibi kurumları,, PERYÖN gibi derneklerin de kongreye katkı sağladığı belirlenmiştir. Son on yılda ise bu kurumların yanında sayıca çok az da olsa insan kaynakları yönetimi konularında uzmanlaşmış danışmanlık şirketleri de kongreye katılım sağlamıştır. (Bkz. Tablo 7)

Kongrede yıllara göre insan kaynakları yönetimi alanında ilk kez çalışılan konular değerlendirildiğinde; bilgi sistemlerin ilk kez 1994 yılında düzenlenen ikinci kongrede çalışıldığı görülmüştür. 1990'l1 yıllarda ön plana çıkan bilgi teknolojilerinin etkisinin yabancı literatürle birlikte kongreye de yansıdı̆̆ 1 söylenebilir. Benzer şekilde 1990 ve 2000'li yıllarla birlikte işletmelerin büyüklüğü ve faaliyet alanının genişlemesi doğrultusunda sayıları giderek artan çok uluslu işletmelerle ilgili ilk bildiri çalışmasının da 2001 y1lında düzenlenen dokuzuncu kongrede olduğu görülmektedir. Yine aynı yıl ülkemizde yaşanan ekonomik krizin etkisiyle, kriz konulu bildiriler kongrede yer almış, bir sonraki yıl düzenlenen kongrede ise kriz en fazla çalışılan bildiri konusu olmuştur. 2000'li yıllarda insan kaynakları yönetiminin stratejik önem kazanması, işletme yeteneklerinin rekabet ile ilişkilendirilmesine yönelik literatürün yansımaları sonucunda, 2003 ve 2004 y1llarında düzenlenen kongrelerde personel güçlendirme, yüksek performans ekipleri ve diş kaynaklardan yararlanma konuları yer almıştır. 2005 yllındaki onüçüncü kongrede insan kaynaklarına pazarlama bakış açısıyla bakılmış, yıllar içinde bu bakış açısının evrilmesiyle 2012'deki kongrede popüler bir kavram olan işveren markası konu başlığı karşımıza çıkmıştır. Yine uygulamada popüler bir kavram olan yetenek 
yönetiminin 2010 yılındaki onsekizinci kongrede, eİKY başlığının 2011 yılındaki ondokuzuncu kongrede, Y kuşağı başlıklı çalışmaların 2012 yılındaki yirminci kongrede ve aynı zamanda örgütsel davranış alanının popüler konu başlıklarından olan iş-yaşam dengesinin 2013 yılındaki yirmibirinci kongrede yer aldığ görülmektedir. (Bkz. Tablo 8)

\section{TARTIŞMA VE SONUÇ}

Türkiye'de personel yönetiminden insan kaynakları yönetimine geçişte yaşanan değişimi incelemeye yönelik yapılan ve alandaki bildiri, makale, tezleri inceleyen farklı çalışmalar bulunmaktadır. $\mathrm{Bu}$ çalışmalar incelendiğinde, ülkemizde alanın Amerika Birleşik Devletleri'nin etkisiyle şekillendiği bir kez daha görülmektedir. Her iki ülkenin yazınında çalışmalar ortaktır ve en çok

Tablo 7: Kongreye Katılan Üniversite ve Kurum Sayıs1

\begin{tabular}{|c|c|c|c|}
\hline Kongre & $\begin{array}{c}\text { Katılan Üniversite } \\
\text { Sayısı }\end{array}$ & Katilan Kurum Sayısı & Toplam \\
\hline 2.Kongre & 3 & - & 3 \\
\hline 4.Kongre & 2 & 1 & 3 \\
\hline 6.Kongre & 1 & - & 1 \\
\hline 7.Kongre & 8 & 1 & 9 \\
\hline 8.Kongre & 13 & - & 12 \\
\hline 9.Kongre & 20 & - & 10 \\
\hline 10.Kongre & 11 & - & 11 \\
\hline 11. Kongre & 9 & - & 9 \\
\hline 12.Kongre & 7 & - & 7 \\
\hline 13.Kongre & 15 & - & 15 \\
\hline 14.Kongre & 15 & 1 & 16 \\
\hline 15.Kongre & 16 & 2 & 18 \\
\hline 16.Kongre & 12 & 1 & 13 \\
\hline 17.Kongre & 18 & 1 & 19 \\
\hline 18. Kongre & 13 & 2 & 15 \\
\hline 19. Kongre & 27 & 3 & 30 \\
\hline 20.Kongre & 18 & 4 & 22 \\
\hline 21.Kongre & 21 & 1 & 22 \\
\hline 22.Kongre & 24 & 2 & 26 \\
\hline 23.Kongre & 38 & 3 & 41 \\
\hline 24.Kongre & 23 & 1 & 24 \\
\hline
\end{tabular}

Tablo 8: Kongrede Yıllara Göre İlk Kez Çalışılan Konu Başlıklarından Bazıları

\begin{tabular}{|c|c|c|c|}
\hline \multirow{2}{*}{$\begin{array}{c}\text { YIL } \\
1994\end{array}$} & \multicolumn{3}{|c|}{ KONGREDE İLK KEZ ÇALIŞILAN KONU BAŞLIKLARI } \\
\hline & Bilgi Sistemleri & & \\
\hline 2001 & Çok Uluslu İşletmeler & - Kadın Çalışanlar & - Kriz \\
\hline 2002 & Iş Sağliğ1 ve Güvenliği & - Ulusal Kalite Ödũlũ & - Kurum Kültürü \\
\hline 2003 & Personel Güçlendirme & - Yüksek Performans Ekipleri & \\
\hline 2004 & D1ş Kaynaklardan Yararlanma & & \\
\hline 2005 & İnsan Kaynaklarına Pazarlama Bakış Açısı & yla Bakma & \\
\hline 2006 & Issyeri Izleme & & \\
\hline 2007 & İşten Ayrılma İsteği & - 360 Derece Geri Bildirim & \\
\hline 2008 & Takım Bazlı Performans Değerlendirme & & \\
\hline 2010 & Yetenek Yönetimi & & \\
\hline
\end{tabular}


çalışılan konuların başında performans yönetimi gelmektedir (Sayılar, 2005; Tuncay, 2015). Yine Amerika Birleşik Devletleri'ndeki literatüre benzer şekilde ülkemizde de performans yönetiminin yanında eğitim ve geliştirme, temin ve seçim, kariyer yönetimi gibi insan kaynakları yönetimi uygulama ve fonksiyonlarını içeren konulara ilginin olduğu görülmektedir (Benligiray, 2009; Sayılar, 2005; Üsdiken \& Wasti, 2002; Yapıc1 - Akar vd., 2011). İnsan kaynakları literatüründe eleştirilere konu olan mikro düzeyde ve yüzeysel analizler ile görgül çalışmaların ön planda olması, ülkemizde de görülen bir durumdur (Sayılar, 2005; Koç vd., 2013). Çalışmalardaki örneklemleri kamu kuruluşları, bankalar, turizm işletmeleri, sağlık kurum ve kuruluşları ile imalat işletmelerinin oluşturduğu görülmektedir (Benligiray, 2009; Sayılar, 2005; Üsdiken \& Wasti, 2002).

Bu çalışmada ise 1993-2016 yıllarında düzenlenen Ulusal Yönetim ve Organizasyon kongrelerinde yayınlanmış, insan kaynakları yönetimi alanındaki bildiriler incelenmiştir. İnsan kaynakları yönetimi alanındaki bildiri sayısının 2004 yılından itibaren artış gösterdiği görülmektedir. Alanda iki yazarlı bildiri sayısı daha fazladır. Bildirilerde yabancı literatürde popülerlik kazanan konular belirleyici olmaya devam etmektedir. Kariyer yönetimi, performans yönetimi gibi temalar alanda en fazla çalışılan konular arasındadır.

Bildiriler araştırma yöntemleri açısından değerlendirildiğinde nicel yöntemlerin tercih edildiği ve anketin halen en çok kullanılan veri toplama tekniği olduğu görülmektedir. Kullanılan nicel yöntemlerin boyut sayıları artmış ve bildiri çalışmalarında insan kaynakları konuları ile örgütsel davranış konuları ilişkilendirilmeye başlamıştır. Benzer şekilde yönetim ve organizasyon kongrelerindeki örgütsel davranış alanında yapılan bildirilerde de araştırma yöntemleri açısından nicel çalışmaların yoğun olarak kullanıldığı görülmektedir (Kızıldağ \& Özkara, 2016). Yine incelenen bildirilerde bankacılık ve finans sektörü ile turizm sektörü en fazla bildiri çalışmasının yapıldığ 1 ilk iki sektör olarak dikkat çekmektedir. Genel olarak değerlendirildiğinde çalışmada, Türkiye'de insan kaynakları alanında yapılmış bildiri, makale ve tez çalışmalarını inceleyen diğer çalışmalarla paralellik gösteren sonuçlara ulaşılmıştır. Yabancı literatürde insan kaynakları yönetimine ilişkin araştırmaların sınırlı bir alana sıkışma ve daha çok insan kaynakları fonksiyonları üzerine çeşitlenme durumu ülkemiz için de geçerliliğini sürdürmektedir. Ülkemizdeki çalışmalar çoğu kez yabancı literatürde yapılan çalışmaların tekrarı niteliğini taşımaktadır.

$\mathrm{Bu}$ çalışmada incelenen bildiriler değerlendirildiğinde de seçilen konular, kullanılan yöntemler ve yapılan değerlendirmeler açısından çalışmaların yeterince özgün olmadığ düşünülebilir. $\mathrm{Bu}$ nedenle benzer çalışmalarda da belirtildiği gibi insan kaynakları alanındaki araştırmacıların daha farklı konuları, makro bakış açısıyla, kalitatif ve karşılaştırmalı olarak incelemesine ihtiyaç duyulmaktadır. Alanda çalışılan konularla ilgili özgünlük ihtiyacı bulunmaya devam etmektedir. Araştırma yapılacak alanın sınırlarının genişletilmesi ve Batı'da geliştirilen mevcut teorileri doğrulayan çalışmalar yerine daha farklı metodolojiler kullanan, disiplinler arası çalışmalara ihtiyaç duyulmaktadır. Son yıllarda kongre bildirilerinde örgütsel davranış alanı ile ortak yapılan çalışmalara rastlanması bu ihtiyacın karşılanması açısından önemli bir gelişmedir. Ancak bu çalışmaların sadece ankete dayalı olmak yerine vakaları ele alması, karşılaştırmalı analizler içermesi ya da farklı metodolojileri bir araya getirmesi önemlidir.

$\mathrm{Bu}$ çalışmada, sadece tek bir ulusal kongrede, kongrenin düzenlenmeye başladığı tarihten itibaren yayımlanan bildiri kitaplarındaki tek bir alandaki bildiriler incelenmiştir. Çalışmadaki sonuçlar, insan kaynakları bildirilerinin de makale ve tez çalışmaları gibi sınırlı bir alana, mikro bakış açısına ve nicel yöntemlere sıkıştığını bir kez daha ortaya koymuştur. $\mathrm{Bu}$ sonuçların bütüncül, makro bakış açısına sahip, yöntem açısından çeşitlenmiş, karşılaştırmalı çalışmalara olan ihtiyacı bir kez daha ortaya koyarak, gelecekte insan kaynakları yönetimi alanında yapılacak araştırmalara katkı sağlaması beklenmektedir. Ayrıca bu çalışma insan kaynakları yönetimi alanıyla ilişkili olan örgütsel davranış literatürünü kapsayacak şekilde, iki alanla ilişkilendirilmiş çalışmaları inceleyecek şekilde genişletilebilir. Gelecekte alanla ilişkili farklı kongrelerin incelendiği ve elde edilecek bulguların karşılaştırıldığı çalışmalar yapılabilir. 


\section{KAYNAKÇA}

Akar, N. (2013). Türk yönetim yazınının son on y1llık kesitinde insan kaynakları yönetimine bakış. Işs, Güç Endüstri İlişkileri ve Insan Kaynakları Dergisi, 15(1), 72-87.

Aycan, Z. (2001). Human resource management in Turkey: Current issues and future challenges, International Journal of Manpower, 22(3), 252-260.

Bayat, B. (2008). İnsan kaynakları yönetiminin stratejik niteliği. Gazi Üniversitesi İktisadi ve İdari Bilimler Fakültesi Dergisi, 10(3), 1-25.

Benligiray, S. (2009). Türkiye'de insan kaynakları yönetimi alanında yapılan lisansüstü tezler ve bu tezlerde incelenen temaların analizi: 1983-2008 dönemi. Eskişehir Osmangazi Üniversitesi İktisadi ve İdari Bilimler Fakültesi Dergisi, 4(1), 167-197.

Erçek, M. (2004). Çeviri, aktör ağları ve eksik/öncül kurumsallaşma: Türkiye'deki mesleki personel/insan kaynakları söyleminin yeniden kurgulanmas1, 1960 1999. Yönetim Araştırmaları Dergisi, 4(2), 129-195.

Eroğlu, O. (2016). 1923’ten günümüze Türkiye'de insan kaynakları yönetiminin gelişimi. Uluslararası Yönetim İktisat ve Issletme Dergisi, 12(29), 181-193.

Kızıldağ, D. \& Özkara, B. (2016). Türkiye'de örgütsel davranış araştırmalarındaki yönelimler: Ulusal yönetim ve organizasyon kongresi örneği. Yönetim Bilimleri Dergisi, 14(28), 611-631.

Koç, U., Türker, Y. \& Özcan, H.M. (2013). Çevredeki bilim: Türkiye'deki insan kaynaklarl yönetimi araştırmaları. 21.Yönetim ve Organizasyon Kongresi, Kütahya, 252-253.

Mahoney, T. A. \& Deckop, J. R. (1986). Evolution of concept and practice in personnel administration/human resource management (PA/HRM). Journal of Management, 12(2), 223-241.

Rotich, K. J. (2015). History, evolution and development of human resource management: a contemporary perspective. Global Journal of Human Resource Management, 3(3), 58-73.

Sağlam Ar1 G. \& Boylu, Y. (2015). İş dünyasına yönelik yayınlarda insan kaynakları yönetimi: Türkiye'de yayınlanan dergiler üzerine bir araştırma. Işsletme Araştırmaları Dergisi, 7(3), 123-142.

Sayılar, Y. (2004). İnsan kaynakları yönetimi alanında kuram ve araştırmanın gelişimi: stratejik olan ve olmayan perspektiflerden bir inceleme. Yönetim Bilimleri Dergisi, 3(1), 45-64.

Sayılar, Y. (2005). İnsan kaynakları yönetimi alanının Türkiye'deki gelişim çizgisi: Yönetim ve organizasyon kongreleri üzerine bir araştırma. Eskişehir Osmangazi Üniversitesi Sosyal Bilimler Dergisi, 6(2), 147-174.

Tuncay, M. (2015). Türkiye ve ABD insan kaynakları yönetimi yazınlarının ele aldıkları konular açısından karşılaştırılması: bir içerek analizi (2004 - 2015). (Yayınlanmamış Yüksek Lisans Tezi). Çankaya Üniversitesi Sosyal Bilimler Enstitüsü, Ankara.

Tunçer, P. (2012). Değişen insan kaynakları yönetimi anlayışında kariyer yönetimi. Ondokuz Mayls Üniversitesi Eğitim Fakültesi Dergisi, 31(1). 203-233.

Üsdiken, B. \& Çetin, D. (1999). Türkiye'de akademik dünyanın yönetme işine yaklaşımında 1950'li yıllarla birlikte ne değişti. Amme İdaresi Dergisi, 32(4), 4765.

Üsdiken, B. \& Wasti, S. A. (2002). Türkiye'de akademik bir inceleme alanı olarak personel veya" insan kaynakları" yönetimi, 1972-1999. Amme İdaresi Dergisi, 35(3), 1-37.

Üsdiken, B. (1996). Importing theories of management and organization: The case of Turkish academia. International Studies of Management \& Organization, 26(3), 33-46.

Van Buren, H. J., Greenwood, M. \& Sheehan, C. (2011). Strategic human resource management and the decline of employee focus. Human Resource Management Review, 21(3), 209-219.

Vani, G. (2011). Evolution of Human Resource Management. Review of Management, 1(2), 127-133.

Wasti, S. A. (1998). Cultural barriers in the transferability of Japanese and American human resources practices to developing countries: The Turkish case. International Journal of Human Resource Management, 9(4), 608-631.

Wright, P. M. \& McMahan, G. C. (1992). Theoretical perspectives for strategic human resource management. Journal of Management, 18(2), 295320 .

Yapıc1-Akar, N., Dirlik, O., Kıymalıoğlu, A., Yurtseven, Ö. \& Boz, H. (2011). Uluslararas1 insan kaynakları yönetimi alanındaki güncel eğilimlerin stratejik yaklaşımlar ve bölgesel modeller açısından değerlendirilmesi: 1998-2008 kesitinde bir inceleme. Business and Economics Research Journal, 2(4), $97-$ 113. 